\title{
Economic Situation of Hog Grower Industry in Nueva Ecija: Problems and Prospects
}

\author{
JOANNIE A. GALANO, Ph. D \\ Chairperson, College of Management - SI Campus \\ Nueva Ecija University of Science and Technology \\ San Isidro, Nueva Ecija, Philippines
}

\author{
ROWELL A. DIAZ, MBA \\ Faculty Member, College of Management - SI Campus \\ Nueva Ecija University of Science and Technology \\ San Isidro, Nueva Ecia, Philippines
}

\begin{abstract}
This study intended to investigate the problem and prospect of the hog raising industry in selected areas in the province of Nueva Ecija. Research questions were formulated and analyzed. The respondents in this study were made up of pig farmers in various types. In the Philippines, agriculture is considered a significant "driver" for economic growth, poverty alleviation, and food security. The general approach in pursuit of development is by increasing agricultural productivity through intensive agriculture and swine production. The different hog farms in the various municipalities in Nueva Ecija were farms whose operation is a sole proprietorship, registered piggery, and at least 45 heads of hogs. The data collected from the respondents were analyzed using simple percentages from the analysis of data; the following were the findings. The farm profile the respondent mainly were classified as a commercial operation, had workers of 1-2 male workers. The farms were involved in the sow-weaning-fattening process, used the traditional type of rearing system, raised 151-200 heads of fattening, 31-40 sow level, 151-200 heads of suckling, and one boar. Most of the respondents had a capital of more than 500,000 and maintained consultancy services with farms visited twice a month. For the majority of pig or hog farmers, the high costs of inputs, particularly in feeds considered as one of the significant problems.
\end{abstract}

Keywords:- Hog Grower, Industry, Swine, Problems, Agriculture, Pig.

\section{INTRODUCTION AND ITS REALATED LITERATURE}

Hog raising is very popular in the Philippines. It is considered as the most significant contributor in the livestock section of agriculture and second to rice production as a contributor to the food basket of the country. Pork is the most widely consumed meat in the world (FAO, 2012). For the hog/pig farmers, livestock plays a central role in their socio-economic and cultural identity. During the past decade hog farming has been transformed along industrialcorporate lines (Owen, 2010). It is a source of food, employment, food security, and store or trade (Whitehead, 2012).

Agriculture is a major industry contributing to the gross domestic product of any country around the global (Mentsiev et al., 2020). The Department of Agriculture classified farm size of the hog raising industry into backyard operation and commercial operations. The agency describes backyard operations as any farm or household raising at least one head of the animal. Swine byproducts are also essential parts of such products as water filters, insulation, rubber, antifreeze, plastics, floor waxes, crayons, chalk, adhesives, and fertilizer (EPA, 2012). Commercial farm refers to any farm or household which satisfies at least one of the following condition: a) with at least 21 heads of adults and zero young b) at least 41 heads of young animals, and c) at least ten heads of adults and 22 heads of young.

Agriculture, in general, but the livestock sector, in particular, faces significant challenges in implementing the green growth strategy. It is because, alongside essential windows of opportunities, especially for smallholder livestock producers, new perils such as environmental pollution and health risks have emerged. At the same time, reservations arise as to whether there is still room for agricultural productivity to increase, where it desired, and the role that small-scale farming will play in the future, if any. Other factors contributing to the increasing widespread consumer acceptance concerning pork and pork products include dietary concerns that favor substitution of red meat with white meat and industry effort in creating added values to respond to consumer demand for innovative and highquality products (Akwetey and Yamoah, 2013).

Like many developing and emerging countries in Asia (e.g., Vietnam, Cambodia, Lao PDR), the swine sector in the Philippines, which is still prevalently small-scale, is a vital source of economic growth. Because pork is an essential source of animal protein, and demand for pork has historically been increasing with an annual per capita consumption of $15.07 \mathrm{~kg}$ (Cabanilla et al 2014). Moreover, the share of pork in meat production maintained at $55 \%$ for more than two decades or between 1990 to 2016 (PSA, 2016). It appeared as potential source of animal proteins and avenues for additional income and employment that can improve the livelihood in a sustainable manner (Petrus et al., 2011). In 2016, the sector's output was valued at USD 4.4 billion. Its contribution to the gross value added in agriculture (GVAA) was estimated at $13.8 \%$, second to the share of paddy rice. Research outputs are transferred to end users in order to enhance swine productivity, industrialization, commercialisation and good resource management practices to improve livelihood (Banson and Danso, 2013). 
ISSN No:-2456-2165

The report of the Philippine Statistics Authority (PSA) for the swine situation as of July 1, 2020, the total swine inventory was estimated at 11.74 million heads, indicating an annual decline of 7.6 percent as $t$ recorded a stock of 12.70 million heads $\mathrm{n}$ the same period of 2019. The population of swine in both backyard and commercial farms posted decreases of 2.7 percent and 15.9 percent, respectively. Of the total swine inventory, 66.5 percent were raised in backyard farms, while 33.5 percent were from commercial farms. By age, the fattener had the highest share $(25.7 \%)$ to total swine inventory, followed closely by grower (24.65). Cabanatuan City, as the center of economic and educational activities in the province of Nueva Ecija, has this one kind of source of livelihood for entrepreneurs (Natividad and Diaz, 2020).

Having set the background and motivation of this study, the main objective of this paper is to determine the problems and prospects of the hog raising industry and its current economic situation in selected areas in the province of Nueva Ecija.

\section{METHODOLOGY}

In this study, the researcher conducted a survey using both interviews and questionnaires to the hog growers in the different municipalities of Nueva Ecija to find out the best practices in production, marketing, and financing aspects.

The researcher mainly focused on the different municipalities of Nueva Ecija namely Aliaga, Bongabon, Cabiao, Carranglan, Cuyapo, Gabaldon, Gen. Mamerto Natividad, Guimba, General Tinio, Jaen, Laur, Licab, Llanera, Lupao, Munoz, Nampicuan, Palayan, Pantabangan, Peñaranda, Quezon, Rizal, San Antonio, San Isidro, San Leonardo, San Jose, Sta. Rosa, Sto. Domingo, Talavera, Talugtug and Zaragoza.

Nueva Ecija is a landlocked province of the Philippines located in the Central Luzon region. Its capital is Palayan City. Nueva Ecija borders from the south clockwise Bulacan, Pampanga, Tarlac, Pangasinan, Nueva Viscaya, and Aurora.

Table 1 shows the distribution of respondents according to the Municipality. Cabiao had seven respondents; San Isidro had six respondents; Gapan, Jaen, Laur, San Antonio, San Jose, and Sta. Rosa had the same respondents of three, Bongabon, Gen. Tinio, Munoz, Palayan, Penaranda, and Rizal had the same respondents of two; Llanera, Lupao, San Leonardo, Sto. Domingo, Talavera, and Gabaldon had the same with one respondent. Other municipalities like Aliaga, Carranglan, Cuyapo, Guimba, Licab, Nampicuan, Pantabangan, Quezon, and Zaragosa had zero registered farms.

\begin{tabular}{|c|c|c|}
\hline & Municipalities/Cities & No. of Respondents \\
\hline 1 & Bongabon & 2 \\
\hline 2 & Cabiao & 7 \\
\hline 3 & Gabaldon & 1 \\
\hline 4 & Gapan & 3 \\
\hline 5 & Gen. Tinio & 2 \\
\hline 6 & Jaen & 3 \\
\hline 7 & Laur & 3 \\
\hline 8 & Llanera & 1 \\
\hline 9 & Lupao & 1 \\
\hline 10 & Munoz & 2 \\
\hline 11 & Palayan & 2 \\
\hline 12 & Penaranda & 2 \\
\hline 13 & Rizal & 2 \\
\hline 14 & San Antonio & 3 \\
\hline 15 & San Isidro & 6 \\
\hline 16 & San Jose & 3 \\
\hline 17 & San Leonardo & 1 \\
\hline 18 & Sta. Rosa & 3 \\
\hline 19 & Sto. Domingo & 1 \\
\hline \multirow[t]{2}{*}{20} & Talavera & 1 \\
\hline & Total & 49 \\
\hline
\end{tabular}

Table 1:- Distribution of Respondents According to Municipalities

The researcher's desired output was achieved thru a data-gathering instrument in the form of a questionnaire, unstructured interviews, and documentary analysis. The statistical treatment utilized a frequency counts and weighted mean.A data-gathering instrument achieved the researcher's desired output in the form of questionnaire, unstructured interviews, and documentary analysis. The statistical treatment utilized frequency counts and weighted mean.

The questionnaire was composed of two parts. The first part included questions regarding the personal and farm profile of the farm owners. The second part was about the grower's practices.

\section{Interview}

The interviews provided data that helped the researcher classify the practices used by hog growers in production, marketing, and financial operation.

\section{Survey}

Through the study conducted, responses of the hog growers about their practices were identified. 
To collect data needed to answer the specific problems, the researcher undertook the following activities: Visit the Municipal Offices of the different municipalities to get the list of registered growers within the vicinity; Visit the hog growers' farm to administer the questionnaires and conduct personal interviews with the respondents; Immediately retrieved of the questionnaire; and lastly, collation, tabulation, and analysis of data.

\section{RESULTS AND DISCUSSION}

\section{* Personal Profile of the Respondents}

There were four (4) variables considered in describing the personal profile of the respondents namely: age, gender, educational attainment and number of year's experience.

Age

\begin{tabular}{|c|c|c|}
\hline Age & Frequency & \% \\
\hline $26-35$ & 3 & 7.14 \\
\hline $36-45$ & 18 & 42.86 \\
\hline $46-55$ & 7 & 16.67 \\
\hline $56-65$ & 10 & 23.81 \\
\hline $66-$ above & 4 & 9.52 \\
\hline Total & 42 & 100 \\
\hline
\end{tabular}

Table 2:- Distribution of the Respondents According to Age

Table 2 shows the distribution of age of respondents in the different municipalities of Nueva Ecija. Based on the table, 18 or $42.86 \%$ of the respondents are aged to age $36-45,10$ or $23.81 \%$ are aged $56-65$, seven or $16.67 \%$ aged $46-45$, and four or $9.52 \%$ aged 66 above, and three or $7.14 \%$ belongs to age 26-35. The eight respondents of the total 49 did not give their response.

Data show that middle-aged individuals are likely to be involved in this kind of business venture. The more mature they are, the more efficient and knowledgeable; they are expected to be more capable of doing a task like traveling from house to farm to visit and supervise the operation of the farm every day.

\section{Gender}

\begin{tabular}{|l|l|l|}
\hline Sex & Frequency & \% \\
\hline Male & 38 & 77.55 \\
\hline Female & 11 & 22.45 \\
\hline Total & 49 & 100 \\
\hline
\end{tabular}

Table 3:- Distribution of Respondents According to Gender

Table 3 shows the gender distribution of respondents. Based on table 38 or $77.55 \%$ are male, and 11 or $22.45 \%$ are female.

Data show that males dominate this kind of business venture. Only a few women ventured into a type of business, maybe because women in rural areas were mostly domesticated in household chores. Based on observation, some of the farms were registered in the name of their wives, but their husband managed the farm.

\section{Educational Attainment}

\begin{tabular}{|c|c|c|}
\hline Degree & Frequency & \% \\
\hline Elementary & 4 & 8.16 \\
\hline Secondary & 7 & 14.28 \\
\hline Tertiary & 32 & 65.32 \\
\hline Post Graduate & 6 & 12.24 \\
\hline Total & 49 & 100 \\
\hline
\end{tabular}

Table 4:- Educational Attainment Distribution of Respondents

Table 4 shows the educational attainment distribution of the respondents. Based on the table, 32 or $65.32 \%$ finished their tertiary level, 7 or $14.28 \%$ finished Secondary level, 4 or $8.16 \%$ finished Elementary level, and 6 or 12.24 finished Post Graduate level.

Data show that majority of the respondents had finished the tertiary level. They are expected to be more qualified to handle the business. Based on the unstructured interview, there are some legalities to be undertaken before the industry becomes registered and licensed. An Environment Compliance Certificate (ECC), request to zone the proposed area from Municipal's Department of Agriculture and training is required. At this point, a person with higher educational qualifications can fully understand the importance of the requirements.

Course of Respondents

\begin{tabular}{|c|c|c|}
\hline Degree & Frequency & \% \\
\hline BSBA & 3 & 9.38 \\
\hline Veterinary Medicine & 6 & 18.75 \\
\hline BS Agronomy & 1 & 3.12 \\
\hline BS Engineering & 8 & 25 \\
\hline Animal Husbandry & 2 & 6.25 \\
\hline BS Economics & 1 & 3.12 \\
\hline BS Nursing & 2 & 6.25 \\
\hline BS Tourism & 1 & 3.12 \\
\hline BS Agriculture & 3 & 9.38 \\
\hline X-ray Technician & 1 & 3.12 \\
\hline BS English & 1 & 3.12 \\
\hline AB Political Science & 2 & 6.25 \\
\hline Midwifery & 1 & 3.12 \\
\hline Total & 32 & 100 \\
\hline
\end{tabular}

Table 5:- Distribution of Respondents According to Course

Table 5 shows the distribution, of course, finished by farm owners. Based on the table, eight or $25 \%$ have a degree of Bachelor of Science in Engineering, six or $18.75 \%$ have a degree in Veterinary Medicine, three or $9.38 \%$ both from Bachelor of Science in Business Administration and Bachelor of Science in Agriculture; two or $6.25 \%$ for A.B. Political Science, Animal Husbandry and Bachelor of 
Science in Nursing; one or $3.23 \%$ for B.S. Agronomy, BS Economics, BS Tourism, Xray Technician, BS English, and Midwifery.

The figure shows that the majority of the respondents finished the Engineering course where their field of expertise can be utilized in designing the facilities, and veterinary medicine, and animal husbandry, where the expertise can be applied on the farm. Based on unstructured interviews, most of the farms owned by a person who had degrees in other courses maintained a consultant who managed their farm or belonged to backyard operation.

\section{Number of Years Experience}

\begin{tabular}{|c|c|c|}
\hline No. of Years & Frequency & \% \\
\hline $1-3$ & 4 & 8.16 \\
\hline $4-6$ & 5 & 10.20 \\
\hline $7-9$ & 2 & 4.08 \\
\hline $10-$ above & 38 & 77.56 \\
\hline Total & 49 & 100 \\
\hline
\end{tabular}

Table 6:- Distribution of Respondents According to Years of Experience in Business

Table 6 shows the distribution of respondents according to experience in hog raising. Based on the table, 38 or $77.46 \%$ have ten years and above, five or $10.20 \%$ have 4-6 years, four or $8.16 \%$ have $1-3$ years, two or 4.08 have 7 9 years of experience.

The figure shows that majority of the respondents had gained enough experience to stay in business for long years and thus have more knowledge, skills, and techniques in managing this business venture. Based on interviews, four respondents had their feed mill. They formulate their mixture of feeds to easily adjust nutrients needed by hogs to avoid interruption of growth of the hogs. For those who are using ready-mixed, which is available in the market, they suggest having feed analysis content.

$>$ Problems met by hog growers

\begin{tabular}{|c|c|c|c|}
\hline & My operation is affected by: & $\begin{array}{c}\text { Weighted } \\
\text { Mean }\end{array}$ & $\begin{array}{c}\text { Verbal } \\
\text { Descri } \\
\text { ption }\end{array}$ \\
\hline 1 & High prices of animal feed. & 4.35 & HA \\
\hline 2 & Control of odor. & 3.06 & AA \\
\hline 3 & Control of disease. & 3.80 & MA \\
\hline 4 & The high cost of labor & 1.41 & NA \\
\hline 5 & Lack of technical knowledge. & 1.90 & NA \\
\hline 6 & Competition with import meat. & 3.47 & MA \\
\hline 7 & Cost of consultancy services. & 3.47 & MA \\
\hline 8 & Cost of medicine & 1.88 & MinA \\
\hline 9 & The low price of live weight & 4.33 & HA \\
\hline 10 & The high cost of tax & 3.12 & AA \\
\hline & Average Weighted Mean & 3.26 & AA \\
\hline
\end{tabular}

Table 7:- Problems Met by Hog Growers

Legend: 5-Highly Affected (HA), 4-Moderately Affected (MA), 3-Averagely Affected (AA),

\section{2-Minimally Affected (MinA), 1-Not Affected (NA)}

Table 7 shows the problems met by hog growers. As can be seen, item 1, "too high prices of animal feeds," got the highest weighted mean of 4.35, meaning "highly affected," followed closely by item 9, "low price of live weight," respectively with a weighted mean of 4.33 indicating "highly affected." There is 1 item with the lowest weighted mean of 1.41 "high cost of labor," which means "not affected." Overall the average weighted mean is 3.26 , meaning "averagely affected."

Based on unstructured interviews, hog growers were affected by too high prices of animal feeds, since most of the growers depend on commercial feeds available in the market. Even feed millers were affected by increased feed ingredients like soya, corn, molasses, etc. Besides this, farmers also fed to their animal the tuber crops like colocasia, tapioca, sweet potato, and many non-conventional kinds of grass; tree leaves either cooked or as raw form, which aligns with the findings of (Lemke et al., 2006; Kumaresan et al., 2009; Moanaro et al., 2011). Base on unstructured interviews with growers, the prices of live weight in Nueva Ecija is lower by P10 per kilo compared to Bulacan and Pampanga. They were also affected by an increase in poll tax and travel permits. Control of odor from the manure of pig was considered as an environmental and health problem. According to the study of Moraes et al., 2017, the implementation of systems that combine agronomic use of manure is necessary to avoid waste of water and volume of waste produced and the swine producer awareness of environmental problems.

\section{CONCLUSION}

The majority of the farm owners were between the ages of 36-45 years old, mostly male, finished tertiary level, having a degree of Bachelor of Science in Engineering, and mostly with experience of more than ten years of hog raising. The farm profile the respondent mainly were classified as a commercial operation, had workers of 1-2 male workers. The farms were involved in the sow-weaningfattening process, used the traditional type of rearing system, raised 151-200 heads of fattening, 31-40 sow level, 151-200 heads of suckling, and one boar. Most of the respondents had a capital of more than 500,000 and maintained consultancy services with farms visited twice a month. Most of the problems of hog growers that positively affect their operation are high in prices of animal feed and low cost of market weight.

\section{RECOMMENDATIONS}

Formulate their feed to reduce the production cost by using locally available feed additives like rice brands instead of pollard. Troubleshooting aspects should be emphasized in the industry, specifically on the identification of the problems and its causes and provide solutions and prevention. Hog growers should aspire for a modern type of facility or design their own based on the farm situation and giving biogas systems to lessen the environmental effects of 
their production. Considering the demand for pork in the province of Nueva Ecija, immense opportunities prevail in the improvement of productivity through adopting scientific interventions in routine management and health care services. Entrepreneurship development in major sectors like feed formulation and supply, establishing pig breeding unit, artificial insemination facilities, mobile vaccination services, pork processing, and use of pork by-products could make the enterprises a profitable one and generate employment opportunities for farmers and youth engaged in this livestock sector.

\section{REFERENCES}

[1]. Briones R. Introduction. In: Briones, R., Sombilla, M., and Balisacan, A. Editors. Productivity growth in Philippine agriculture. Philippines: SEARCADABAR-PhilRice; 2014.

[2]. Cabanilla LS, Rodriqguez UPE, Quilloy AJA. Hog Industry. In Briones, R., M. Sombilla, and A. Balisacan, Editors. Productivity Growth in Philippine Agriculture. Philippines: SEARCA-DABAR-PhilRice; 2014

[3]. Choi J, Roberts DC. Impacts of air pollution on productivity growth in the air and truck transportation industries in the US: An application of the data envelopment analysis Malmquist environmental productivity index. Open Journal of Social Sciences. 2015;(3):120- 129.

[4]. Gerber P, Henderson B, Makkar P, Editors. Mitigating greenhouse gas emissions from livestock. Italy: FAO; 2012

[5]. Kumaresan A., Bujarbaruah K.M., Pathak K.A., Das A., Bardoloi R.K. 2009. Integrated resource-driven pig production systems in a mountainous area of Northeast India: production practices and pig performance. Tropical Animal Health and Production, 41:11871196.

[6]. Lemke U., Kaufmann B., Thuy L.T., Emrich K. and Valle Zarate A. 2006. Evaluation of smallholder pig production system in North Vietnam. Agricultural Systems, 96, 207-223.

[7]. Mentsiev, Adam \& Amirova, E \& Afanasev, N. (2020). Digitalization and mechanization in agriculture industry. IOP Conference Series: Earth and Environmental Science. 548. 032031. 10.1088/17551315/548/3/032031

[8]. Moanaro, Ngullie E., Walling I., Krose M. and Bhatt B.P. 2011. Traditional Animal Husbandry Practices in Tribal States of Eastern Himalaya, India: A Case Study. Indian Journal of Animal Nutrition, 28: 23-28.

[9]. Moraes, R. \& Silveira, R. \& Vaniel, C. \& Pinheiro, L. \& Ollé, M. \& Silveira, Isabella. (2017). Swine production and the environment. Review. Revista Electronica de Veterinaria. 18.

[10]. Natividad, Nestor \& Diaz, Rowell. (2020). Business Operational Analysis of Fitness Gym \& Wellness Services.
[11]. Petrus N.P., Mpofu I., Schneider B.M. and Nepembe M. 2011. The constraints and potentials of pig production among comunal farmers in Etayi Constituency of Nambia. Livestock Research for Rural Development, 23: 159.

[12]. Philippine Statistics Authority (PAS). Swine industry performance report, January to June 2016. Available:https://psa.gov.ph/ content/swine-industryperformancereport-january-june-2016case study,Total Quality Management \& Business Excellence, 20:5,467482,DOI: $10.1080 / 14783360902863614$

[13]. Teruel R, Briones R, Paredes A. Measuring and explaining productivity and growth: Theory and methods. In: Briones, R., Sombilla, M., and Balisacan, A. Editors. Productivity growth in Philippine agriculture. Philippines: SEARCA-DABAR-PhilRice; 2014. 